\title{
ANALISIS IMPLEMENTASI PENGUATAN PENDIDIKAN KARAKTER DALAM PEMBELAJARAN PPKn (STUDI KASUS DI SD NEGERI 1 SUROTRUNAN TAHUN AJARAN 2019/2020)
}

\author{
Nadya Vera Wibowo ${ }^{1}$, Rokhmaniyah $^{2}$, Kartika Chrysti Suryandari ${ }^{3}$ \\ Sebelas Maret University \\ nadyavera97@gmail.com
}

\author{
Article History \\ accepted 01/10/2020
}

approved 01/11/2020

published 01/12/2020

\begin{abstract}
It is crucial to implement student character values from early age. The application of character education has been implemented at $S D N 1$ Surotrunan. To determine the of student character values, the researcher was interested in evaluating the implementation of strengthening character education at SDN 1 Surotrunan. The study aimed to describe the implementation of strengthening character education in Pancasila and Civic Education and to analyze the factors that affected strengthening character education in Pancasila and Civic Education at S D N 1 Surotrunan. The data were narration about research subjects obtained through data collection techniques included observation, interviews, and document study. The participants were students, class teachers, and principal. The data validity test techniques were source triangulation and technique triangulation. Data analysis techniques were data reduction, data presentation, and verification. (1) The student character values that can be observed in $S D$ Negeri 1 Surotrunan are: (a) religious; (b) honest; (c) tolerance; (d) discipline; (e) care for the environment; (f) social care; $(g)$ and responsibilities. Overall, the students' character values have been optimal, there are only a few values that have not been fulfilled optimally. Values that are not optimal in instilling character values are tolerance, environmental care, and social care; (2) factors affecting the strengthening character education in Pancasila and Civic Education were internal and external factors. Internal factors included: (a) feeling, (b) habit, (c) willingness, (d) mood, and (e) offspring. External factors included education and environment.
\end{abstract}

Keywords: analysis, strengthening character education

\begin{abstract}
Abstrak: Penerapan nilai karakter siswa sejak dini penting dilakukan, di SD N 1 Surotrunan penerapan pendidikan karakter sudah diterapkan. Untuk mengetahui nilai karakter siswa, peneliti tertarik untuk menganalisis implementasi Penguatan Pendidikan Karakter di SD N 1 Surotrunan. Tujuan penelitian ini yaitu mendeskripsikan implementasi Penguatan Pendidikan Karakter dalam pembelajaran PPKn, menganalisis faktor yang mempengaruhi Penguatan Pendidikan Karakter dalam pembelajaran PPKn di SD N 1 Surotrunan. Data berupa kalimat atau narasi peneliti mengenai subjek penelitian yang diperoleh melalui teknik pengumpulan data yaitu observasi, wawancara, dan dokumentasi. Partisipan penelitian adalah siswa, guru kelas, dan kepala sekolah. Teknik uji validitas data menggunakan triangulasi sumber dan teknik. Teknik analisis data yaitu: reduksi data, penyajian data, dan verifikasi. (1) Nilai karakter siswa yang dapat diamati di SD Negeri 1 Surotrunan yaitu: (a) religius; (b) jujur; (c) toleransi; (d) disiplin; (e) peduli lingkungan; (f) peduli sosial; (g) dan tanggung jawab. Secara keseluruhan nilai-nilai karakter siswa sudah optimal, hanya ada beberapa nilai yang belum terpenuhi secara optimal. Nilai yang belum optimal dalam penanaman nilai-nilai karakter yaitu (a) toleransi; (b) peduli lingkungan; (c) dan peduli sosial; (2) faktor yang mempengaruhi Penguatan Pendidikan Karakter dalam pembelajaran PPKn faktor intern dan faktor ekstern, faktor intern meliputi: (a) insting atau naluri; (b) adat atau kebiasaan (habit); (c) kehendak atau kemauan; (d) suasana batin atau suasana hati; (e) keturunan. Faktor ekstern meliputi: (a) pendidikan; (b) lingkungan.
\end{abstract}

Kata Kunci: analisis, penguatan pendidikan karakter 


\section{PENDAHULUAN}

Abad 21 ditandai dengan berbagai macam perubahan antara lain banyak orang beranggapan bahwa pendidikan karakter anak pada zaman dahulu lebih bagus dibandingkan zaman sekarang. Sepertinya anggapan tersebut benar adanya, karena melihat sikap sebagian besar anak zaman sekarang yang kian membuat orang dewasa mengelus dada. Anak SD banyak melawan guru dan orang tuanya, terlibat perkelahian, merokok, menggunakan obat terlarang hingga melakukan tindak asusila. Jika kita mencermati kembali, masalah ini berkembang semakin parah seiring dengan meningkatnya kecanggihan teknologi yang tidak terkontrol. Kebebasan anak-anak mengakses internet dengan segala dunianya, membuat mereka terfokus hanya pada apa yang mereka lihat di internet. Mereka menganggap apa yang terjadi di luar sana adalah hal yang wajar dilakukan, bahkan sangat baik untuk ditiru. Itulah salah satu dampak negatif kecanggihan teknologi.

Meski buruk bagi aspek moral anak, namun perkembangan teknologi tetap saja tidak dapat dicegah. Kita tidak dapat menghentikan laju teknologi, namun yang dapat kita lakukan yaitu memperketat pengawasan dan pendidikan karakter kepada anak. Dua peran yang paling bertanggung jawab dalam mengemban tugas ini yaitu orang tua dan guru/pendidik. Keduanya sangat berpengaruh dalam pembentukan karakter anak.

Penerapan penguatan pendidikan karakter di sekolah bisa menjadi solusi guna mengatasi permasalahan di atas. Koesoema (2010: 116) berpendapat bahwa pendidikan karakter yang diterapkan dalam lembaga pendidikan bisa menjadi salah satu sarana pemanusiaan dan pembudayaan. Sejalan dengan pendapat tersebut, Ardyi (2013: 98) mengatakan bahwa sekolah berfungsi sebagai wahana transformasi nilai-nilai luhur yang akan menentukan corak berpikir dan berperilaku anak sesuai norma di masyarakat melalui pendidikan karakter. Nilai-nilai yang ditanamkan sejak dini, berawal dari pembiasaan dan cepat lambat membudaya dalam diri siswa menjadi suatu karakter. Apabila nilai-nilai tersebut telah melekat pada diri siswa, maka siswa akan memiliki komitmen dalam melaksanakan nilai-nilai tersebut.

Pada kurikulum 2013 karakter dibentuk sejak dini. Pendidikan karakter berhubungan erat dengan nilai-nilai karakter yang akan ditanamkan dalam diri peserta didik. Lickona (2012: 74) menjelaskan bahwa sikap hormat dan bertanggung jawab adalah nilai dasar yang harus diajarkan di sekolah. Menurut Kemendikbud (Zubaedi, 2011: 75-76) juga memaparkan beberapa nilai karakter yang harus dicapai di tingkat sekolah. Nilai-nilai tersebut diidentifikasi berasal dari empat sumber yaitu agama, Pancasila, budaya, dan tujuan pendidikan nasional. Berdasarkan keempat sumber tersebut dapat diidentifikasi 18 nilai karakter yang dapat dikembangkan melalui pendidikan karakter di satuan pendidikan, di antaranya adalah religius, jujur, toleransi, disiplin, kerja keras, kreatif, mandiri, demokratis, rasa ingin tahu, semangat kebangsaan, cinta tanah air, menghargai prestasi, bersahabat, cinta damai, gemar membaca, peduli lingkungan, peduli sosial, dan tanggung jawab.

Pada era globalisasi ini, bangsa Indonesia berada dalam proses perjalanan bangsa menuju masyarakat madani, pendidikan kewarganegaraan yang merupakan mata pelajaran di sekolah perlu menyesuaikan diri sejalan kebutuhan masyarakat yang sedang berubah. Pendidikan Kewarganegaraan berorientasi pada penanaman konsep kenegaraan dan juga bersifat implementatif dalam kehidupan sehari-hari.

SD N 1 Surotrunan adalah SD di Kecamatan Alian yang merupakan SD inklusi yang berupaya menerapkan Penguatan Pendidikan Karakter dalam pembelajaran. Pendidikan untuk anak berkebutuhan khusus terus mengalami pembaharuan sehingga muncul istilah pendidikan inklusi. Pendidikan inklusi mencerminkan pendidikan untuk semua serta memberikan kesempatan bagi siswa berkebutuhan khusus untuk dapat 
belajar bersama-sama dengan teman sebayanya di sekolah umum. Akan tetapi, masih adanya masalah pada sekolah inklusi dan belum semua siswa dapat menerima kehadiran siswa yang berkebutuhan khusus. Kurangnya sikap toleransi dan menghargai masih menjadi masalah yang dihadapi pada sekolah inklusi saat ini. Mumpuniarti (2012: 254) menyatakan bahwa penciptaan suatu kondisi akan mendorong siswa-siswa di sekolah dasar inklusi belajar mengimplementasikan karakter dalam kehidupan sehari-hari.

Di SD N 1 Surotrunan penanaman karakter masih rendah, materi tentang karakter hanya diberikan pada pembelajaran saja, sehingga karakter siswa kurang untuk digali oleh guru. Cara guru mengajar masih menggunakan cara tradisional atau menggunakan ceramah dan siswa mengerjakan lembar kerja siswa. Terdapat beberapa nilai, salah satunya yaitu nilai toleransi siswa yang masih rendah. Hal ini ditandai dengan siswa masih membeda-bedakan teman terutama siswa yang berkebutuhan khusus. Karakter pada sekolah dasar terintegrasi pada mata pelajaran PPKn, hal ini dibuktikan dengan adanya mata pelajaran PPKn.

Berdasarkan obervasi dilapangan peneliti memilih salah satu sekolah yaitu SD N 1 Surotrunan dengan jumlah siswa sebanyak 108 anak. Siswa kelas I berjumlah 19 anak dengan siswa laki-laki berjumlah 14 anak dan perempuan berjumlah 5 anak, dengan siswa berkebutuhan khusus berjumlah 3 anak. Kelas II berjumlah 21 anak dengan siswa laki-laki berjumlah 10 anak dan perempuan berjumlah 11 anak, dengan siswa berkebutuhan khusus berjumlah 3 anak. Kelas III berjumlah 17 anak dengan siswa laki-laki berjumlah 7 anak dan perempuan berjumlah 10 anak, dengan siswa berkebutuhan khusus berjumlah 4 anak. Kelas IV berjumlah 23 anak dengan siswa laki-laki berjumlah 10 anak dan perempuan berjumlah 13 anak, dengan siswa berkebutuhan khusus berjumlah 4 anak. Kelas $\mathrm{V}$ berjumlah 28 anak dengan siswa lakilaki berjumlah 15 anak dan perempuan berjumlah 13 anak, dengan siswa berkebutuhan khusus berjumlah 2 anak. Karakter kelas rendah tentu berbeda dengan kelas tinggi. Pada siswa kelas rendah belum dapat mengembangkan keterampilan kognitifnya secara penuh, sedangkan siswa di kelas tinggi sudah dapat berfikir, berkreasi secara luas.

Ardy (2013: 70) menjelaskan bahwa karakter adalah watak, tabiat, akhlak, atau ciri kepribadian seseorang yang terbentuk dari hasil internalisasi berbagai nilai kebajikan (virtues) yang diyakini dan digunakan sebagai landasan berpikir, bersikap, dan bertindak. Pembelajaran karakter yang ditanamkan sejak usia dini dapat dilakukan dengan berbagai kegiatan belajar yang disesuaikan dengan kebutuhan, potensi, bakat dan minat anak. Sementara itu, Hariyanto (2013: 42) menjelaskan bahwa karakter adalah nilai-nilai yang unik yang terpatri dalam diri dan terwujudkan dalam perilaku.

Menurut Mahmud (2017: 24) menyatakan bahwa pendidikan karakter adalah segala sesuatu yang dilakukan guru, yang mampu mempengaruhi karakter peserta didik. Menurut Oktaviani (2018: 118) character education is an effort to implant the intelligence in thinking, appreciation in the form of attitudes, and experiences in the form of behavior in accordance with the noble values that become his identity, manifested in interaction with his God, oneself, between people and environment. Pendapat tersebut diartikan pendidikan karakter adalah upaya menanamkan kecerdasan dalam berpikir, penghargaan dalam bentuk sikap, dan pengalaman dalam bentuk perilaku yang sesuai dengan nilai-nilai luhur yang menjadi identitasnya, dimanifestasikan dalam interaksi dengan Tuhannya, diri sendiri, antara manusia dan lingkungannya. Menurut Safitri (2019: 241) character education is one of the main issues of education. Character education is expected to be able to shape the morals of the nation's children and become the main foundation to improve the nation's dignity. 
True character education is in the identity and behavior of each individual given by God. Pendapat tersebut diartikan pendidikan karakter adalah salah satu masalah utama pendidikan.

Pendidikan karakter hendaknya dilakukan dalam lingkungan keluarga, lembaga pendidikan, dan masyarakat. Pendidikan karakter dalam lembaga pendidikan, menurut Sri (2011: 79) merupakan keseluruhan proses pendidikan yang dialami peserta didik sebagai pengalaman pembentukan kepribadian melalui memahami dan mengalami sendiri nilai-nilai, keutamaan-keutamaan moral, nilai-nilai ideal agama, nilai-nilai moral Pancasila, dan sebagainya. Sejalan dengan pendapat tersebut, Koesoema (2010: 193) menjelaskan bahwa pendidikan karakter di sekolah mengacu pada proses penanaman nilai, berupa pemahaman-pemahaman, tata cara merawat dan menghidupi nilai-nilai itu, serta bagaimana seorang siswa memiliki kesempatan untuk dapat melatihkan nilainilai tersebut secara nyata.

Berdasarkan latar belakang masalah yang telah dipaparkan oleh peneliti, maka dapat dipaparkan rumusan masalah sebagai berikut: (1) Bagaimana implementasi Penguatan Pendidikan Karakter dalam pembelajaran PPKn di SD Negeri 1 Surotrunan tahun ajaran 2019/2020?; (2) Apa sajakah faktor yang mempengaruhi Penguatan Pendidikan Karakter dalam pembelajaran PPKn di SD Negeri 1 Surotrunan tahun ajaran 2019/2020?

\section{METODE}

Penelitian ini merupakan penelitian kualitatif dengan tipe narasi design. Subjek penelitian ini adalah siswa SD N 1 Surotrunan. Penelitian ini dilaksanakan di SD N 1 Surotrunan yang berlangsung dari bulan November 2019 sampai Maret 2020.

Penelitian ini mendeskripsikan aspek karakter siswa SD N 1 Surotrunan. Selain itu dalam penelitian ini peneliti akan menganalisis faktor yang mempengaruhi karakter siswa. Subjek dalam penelitian ini adalah siswa kelas I-V, guru kelas I-V, dan kepala sekolah.

Data yang diambil untuk penelitian ini adalah data kualitatif. Sumber data dalam penelitian ini terdiri dari tempat dan peristiwa, serta informan. Teknik pengumpulan data pada penelitian ini terdiri dari observasi, wawancara, dan dokumentasi. Teknik uji validitas data pada penelitian ini adalah teknik triangulasi sumber.

Teknik analisis data pada penelitian ini mengacu pada model analisis data menurut Prastowo, (2012: 241) yang terdiri dari reduksi data, penyajian data, dan penarikan kesimpulan atau verifikasi. Tahapan penelitian ini meliputi: (1) tahap pra lapangan terdiri; (2) tahap pekerjaan lapangan; (3) tahap analisis data; (4) tahap validitas data.

\section{HASIL DAN PEMBAHASAN}

Berdasarkan hasil observasi, wawancara, dan studi dokumen yang telah dilaksanakan di SD N 1 Surotrunan dengan subjek siswa kelas I-V, guru kelas I-V, dan kepala sekolah. Bahwa proses pembelajaran karakter masih terintegrasi dengan proses pembelajaran tematik. Proses pembelajaran karakter masih tergolong rendah yaitu 66.67\%. Menurut Aqib (2011: 7-8) mengemukakan bahwa terdapat 18 nilai karakter yaitu religius, jujur, toleransi, disiplin, kerja keras, kreatif, mandiri, demokratis, rasa ingin tahu, semangat kebangsaan, cinta tanah air, menghargai prestasi, komunikatif, cinta damai, gemar membaca, peduli lingkungan, peduli sosial, dan tanggung jawab. Berdasarkan kajian teori mengenai nilai-nilai karakter di atas, dalam pelaksanaan pendidikan karakter pada kelas inklusi, peneliti condong pada nilai-nilai karakter seperti religious, jujur, toleransi, disiplin, peduli lingkungan, peduli sosial, dan 
tanggung jawab. Nilai tersebut merupakan bentuk toleransi dan peduli yang merupakan nilai inti dalam penelitian ini. Toleransi memuat unsur saling menghormati, menerima, penghormatan terhadap perbedaan, penghormatan terhadap kelompok minoritas, dan terbuka. Sedangkan peduli memuat unsur cinta, peduli, dan kemurahan hati (Budiyanto, 2005: 73-74). Berikut ini merupakan hasil penelitian tentang nilai karakter siswa :

Tabel Hasil Penelitian Evaluasi Nilai Karakter Siswa

\begin{tabular}{|l|l|l|}
\hline No. & Aspek yang diamati & Hasil penelitian \\
\hline 1. & Religius & $\begin{array}{l}\text { Siswa sudah terbiasa tadarus dan } \\
\text { berdoa secara mandiri sebelum } \\
\text { pelajaran berlangsung, berdoa } \\
\text { setelah selesai pembelajaran, dan } \\
\text { mengucapkan salam pada guru. }\end{array}$ \\
\hline 2. & Jujur & $\begin{array}{l}\text { Siswa mengatakan yang } \\
\text { sebenarnya. Misalnya terkait dengan } \\
\text { PR, siswa jujur apabila belum } \\
\text { mengerjakan PR. Kemudian siswa } \\
\text { juga jujur untuk mengakui jika } \\
\text { jawabannya salah. Selain itu, siswa } \\
\text { juga tidak mencontek ketika } \\
\text { ulangan. }\end{array}$ \\
\hline 3. & Toleransi & $\begin{array}{l}\text { Siswa kurang dapat bermain } \\
\text { bersama, bercanda, dan berbaur } \\
\text { dengan temannya yang } \\
\text { berkebutuhan khusus. }\end{array}$ \\
\hline 4. & Disiplin & $\begin{array}{l}\text { Siswa sudah mengerjakan kegiatan } \\
\text { tepat waktu, tidak ramai di kelas, } \\
\text { mengerjakan tugas/PR dari guru, } \\
\text { dan mengumpulkan tugas sesuai } \\
\text { kesepakatan bersama. }\end{array}$ \\
\hline 5. & Peduli sosial & $\begin{array}{l}\text { Siswa dibiasakan untuk membuang } \\
\text { sampah pada tempatnya. Namun, } \\
\text { masih ada juga siswa yang } \\
\text { membuang sampah sembarangan. }\end{array}$ \\
\hline 5. & Peduli lingkungan & $\begin{array}{l}\text { Peduli sosial tampak ketika siswa } \\
\text { biasa peduli terhadap temannya } \\
\text { yang membutuhkan. Namun, ada } \\
\text { juga siswa yang kurang bersedia } \\
\text { membantu temannya yang } \\
\text { berkebutuhan khusus. }\end{array}$ \\
\hline $\begin{array}{l}\text { Siswa sudah terbiasa bertanggung } \\
\text { jawab melaksanakan piket sesuai } \\
\text { jadwal dan bertanggung jawab } \\
\text { mengerjakan PR/ tugas dari guru. }\end{array}$ \\
\hline
\end{tabular}

Pelaksanaan pendidikan karakter sangat penting diterapkan sejak dini. Hal ini bertujuan untuk menanamkan karakter sejak dini yang terintegrasi pada kegiatan pembelajaran. Hal ini sesuai dengan pendapat Koesoema (2010: 116) menyatakan bahwa pendidikan karakter yang diterapkan dalam lembaga pedidikan bisa menjadi salah satu sarana pemanusiaan dan pembudayaan. Tujuan dari penanaman karakter 
sejak dini yaitu untuk mengembangkan karakter, dengan pelaksanaan yang masih terintegrasi pada kegiatan pembelajaran. Pelaksanaan pendidikan karakter di SD N I Surotrunan masih terintegrasi dengan kegiatan pembelajaran sehingga penanaman karakter siswa masih kurang optimal.

Fakor-faktor yang mempengaruhi karakter siswa SD N 1 Surotrunan terdiri dari faktor intern dan faktor ekstern. Faktor intern yaitu: (a) Insting atau naluri. Secara keseluruhan tingkat insting atau naluri siswa dalam pendidikan karakter sudah cukup baik, jika siswa mempunyai insting atau naluri dalam karakter, maka siswa akan melakukan suatu kegiatan yang yang menjadi sarana pemanusiaan dan pembudayaan. $\mathrm{Hal}$ ini sejalan dengan pendapat Koesoema (2010: 116) menyatakan bahwa pendidikan karakter yang diterapkan dalam lembaga pedidikan bisa menjadi salah satu sarana pemanusiaan dan pembudayaan. Tetapi ada beberapa nilai yang belum terpenuhi atau belum muncul karena ada beberapa yang mempengaruhi, yaitu: (1) toleransi; (2) peduli lingkungan; (3) dan peduli sosial; (b) Adat atau kebiasaan (habit). Tingkat adat atau kebiasaan (habit) siswa cukup baik, dengan beberapa nilai yang terpenuhi sudah bisa mengambarkan adat atau kebiasaan (habit) siswa dalam penanaman karakter siswa; (c) Kehendak atau kemauan. Kehendak dan kemauan sangat mempengaruhi penanaman karakter sejak dini, kehendak atau kemauan yang sungguh-sungguh akan mendukung penanaman karakter siswa dapat tumbuh dengan baik. Tingkat kehendak atau kemauan siswa cukup baik, namun siswa masih belum sungguh-sungguh untuk berperilaku; (d) Suasana batin atau suasana hati. Suasana batin atau suasana hati juga mempunyai peran penting dalam penanaman karakter siswa. Suasana batin atau suara hati siswa sangat mempengaruhi karakter siswa, dengan beberapa nilai yang terpenuhi sudah bisa mengambarkan bahwa suasana batin atau suara hati siswa sangat mendukung dalam penanaman karakter siswa; (e) Keturunan. Keturunan juga mempunyai peran penting dalam penanaman karakter siswa. Secara keseluruhan pendidikan di keluarga sudah bagus, orang tua memantau perkembangan siswa, siswa dapat menyelesaikan tugas dengan benar, walaupun dibantu oleh orang tua. Siswa juga berperilaku jujur di lingkungan keluarga, dalam memanfaatkan waktu dengan baik, siswa masih dibantu oleh orang tua, orang tua menerapkan jadwal kegiatan siswa untuk memanfaatkan waktu dengan baik. Rata-rata siswa saling menghargai di lingkungan rumah maupun di lingkungan masyarakat, siswa mudah berbaur dengan orang lain dan siswa senang jika membantu orang tua, walaupun ada beberapa yang malas membantu orang tua. Sedangkan faktor ekstern yaitu: (a) Pendidikan. Pendidikan sangat mempengaruhi penanaman karakter sejak dini, lingkungan sekolah yang mendukung dengan fasilitas yang baik maka karakter siswa dapat tumbuh dengan baik. Melalui pembelajaran sehari hari, guru dapat memahami karakter anak, minat anak, dan potensi anak. Pendidikan mendukung dalam penanaman karakter sejak dini, di sekolah siswa dapat bertemu dan belajar bersama dengan siswa yang lain, sehingga akan melatih karakter siswa sejak dini. Lingkungan sekolah yang sudah mendukung penanaman karakter, sebaiknya guru dan kepala sekolah memanfaatkannya dengan baik agar karakter siswa dapat berkembang dengan optimal; (b) Lingkungan. Llingkungan juga mempunyai peran penting dalam penanaman karakter siswa. Secara keseluruhan pendidikan di lingkungan sudah bagus. Siswa juga berperilaku jujur di lingkungan sekitar, dalam memanfaatkan waktu dengan baik, siswa masih dibantu oleh lingkungan sekitar. Rata-rata siswa saling menghargai di lingkungan rumah maupun di lingkungan masyarakat. Siswa juga mudah berbaur dengan orang lain. 


\section{SIMPULAN}

Berdasarkan hasil penelitian dan pembahasan yang telah diuraikan, maka simpulan dari penelitian ini adalah: (1) Nilai karakter siswa yang dapat diamati di SD N 1 Surotrunan yaitu: a) religius; b) jujur; c) toleransi; d) disiplin; e) peduli lingkungan; f) peduli sosial; g) dan tanggung jawab. Secara keseluruhan nilai-nilai karakter siswa sudah optimal dan penanaman karakter siswa berkembang dengan baik hanya ada beberapa nilai yang belum terpenuhi secara optimal. Nilai yang belum optimal dalam penanaman nilai-nilai karakter yaitu: a) toleransi; b) peduli lingkungan; c) dan peduli sosial. (2) Faktor- faktor yang mempengaruhi karakter siswa terdiri dari faktor intern dan faktor ekstern. Faktor intern: (a) Insting atau naluri. Tingkat kemauan siswa dalam menanamkan nilai-nilai karakter akan tinggi, jika siswa melakukan suatu kegiatan yang mendukung dalam penanaman karakter meskipun melakukan kegiatan dengan purapura ataaupun dalam kenyataan.; (b) Adat atau kebiasaan (habit). Adat atau kebiasaan (habit) siswa dalam menanamkan nilai-nilai karakter bisa di lihat dari beberapa aspek seperti religious, jujur, toleransi, disiplin, kerja keras, kreatif, mandiri, demokratis, rasa ingin tahu, semangat kebangsaan, cinta tanah air, menghargai prestasi, komunikatif, cinta damai, gemar membaca, peduli lingkungan, peduli sosial, dan tanggung jawa. Jika beberapa aspek dapat terpenuhi maka siswa mempunyai rasa tertarik pada nilainilai karakter; (c) Kehendak atau kemauan. Tingkat kehendak atau kemauan siswa dalam berkarakter akan tinggi, jika siswa melakukan suatu kegiatan yang mendukung dalam berkarakter meskipun melakukan kegiatan dengan pura-pura ataaupun dalam kenyataan; (d) Suasana batin atau suasana hati. Suasana batin atau suasana hati juga mempunyai peran penting dalam penanaman karakter siswa. Jika beberapa nilai dapat terpenuhi maka siswa mempunyai rasa tertarik pada nilai-nilai karakter; (e) Keturunan. Keturunan atau lingkungan keluarga juga mempunyai peran penting dalam penanaman nilai-nilai karakter siswa. Orang tua merupakan guru pertama dengan penuh kasih sayang membimbing dan banyak memberikan pengaruh warna kepribadian anak sehingga keinginan yang besar dari anak menjadi mudah diwujudkan. Faktor ekstern: (a) Pendidikan. Pendidikan atau lingkungan sekolah sangat mempengaruhi penanaman nilai-nilai karakter sejak dini, lingkungan sekolah yang mendukung dengan fasilitas yang baik maka nilai-nilai karakter siswa dapat tumbuh dengan baik; (b) Lingkungan. Lingkungan mempunyai peran penting dalam penanaman karakter siswa. Rata-rata siswa saling menghargai di lingkungan rumah maupun di lingkungan masyarakat. Siswa juga mudah berbaur dengan orang lain.

Berdasarkan uraian hasil penelitian, implikasi dari penelitian ini yaitu: (1) bagi sekolah, hasil penelitian ini dapat dijadikan dasar untuk melakukan penanaman nilainilai karakter siswa agar dapat optimal dalam pelaksanaannya; (2) guru sebagai pelaksana pembelajaran dapat melaksanakan inovasi pembelajaran yang dapat digunakan untuk mengintegrasikan pendidikan karakter, seperti PPR, bermain peran, TGT, ARCS, dan simulasi serta pemanfaatan media pembelajaran agar penanaman nilai-nilai karakter siswa dapat di tanamkan secara optimal; (3) Siswa sebagai pelaksana penanaman nilai-nilai karakter dapat dijadikan dasar untuk lebih memahami informasi yang diberikan guru dalam mengembangkan nilai-nilai karakter sejak dini; (4) Bagi peneliti selanjutnya yang mengangkat topik hampir sama, seperti permasalahan mengenai kendala-kendala dalam melakukan penanaman karakter. Hasil penelitian ini dapat dijadikan sebagai pedoman untuk penelitian yang lebih mendalam terutama pada topik nilai-nilai karakter siswa.

\section{DAFTAR PUSTAKA}


A, Doni Koesoema (2010). Pendidikan Karakter: Strategi Mendidik anak di Zaman Global. Jakarta: Grasindo.

Aqib, Zainal. (2011). Panduan dan Aplikasi Pendidikan Karakter. Bandung: Yrama Widya.

Mahmud. (2017). Pendidikan Karakter Konsep dan Implementasi. Bandung: Alfabeta.

Mumpuniarti. (2012). Pembelajaran Nilai Keberagaman dalam Pembentukan Karakter Siswa di Sekolah Dasar Inklusi. Jurnal Pendidikan Karakter. (Nomor 3 tahun 2). Hlm. 248-257. Diperoleh pada 29 Desember 2019.

Narwanti, Sri. (2011). Pendidikan Karakter. Yogyakarta: Grup Relasi inti Media.

Oktaviani, Rizka Nur, dkk. (2018). The Effect of Using Children's Literature Supplement Book Oriented in Caracter Education to Poem Writhing Skills for 6th Grade of Elementary School. Journal of Education Vol. 1, 2018 pp. 118. Diperoleh pada 01 Januari 2020.

Prastowo, Andi (2012). Metode Penelitian Kualitatif dalam Perspektif Rancangan Penelitian. Yogyakarta: Ar-Ruzz Media.

Safitri, Novia Faiz, dkk. (2019). Strengthening the Character Education based on the Social Skills of Students in the Integrated Thematic Learning in Primary Schools. Journal of Educational Management Vol. 8 No. 2, 2019 pp. 240-247. Diperoleh pada 01 Januari 2020.

Samani, Muchlas dan Hariyanto. (2013). Konsep dan Model Pendidikan Karakter. Bandung: PT Remaja Rosdakarya.

Thomas, Lickona. (2012). Mendidik untuk Membentuk Karakter: Bagaimana Sekolah dapat Memberikan Pendidikan tentang Sikap Hormat dan Tanggung Jawab. Penerjemah: Juma Abdu Wamanungo. Jakarta: Bumi Aksara.

Wiyani, Novan Ardy. (2013). Konsep Praktik dan Strategi Membumikan Pendidikan Karakter di Sekolah Dasar. Yogyakarta: Ar- Ruzz Media.

Zubaedi. (2011). Desain Pendidikan Karakter: Konsepsi dan Aplikasinya dalam Lembaga Pendidikan. Jakarta: Kencana. 